\title{
Faktor-Faktor Yang Berhubungan Dengan Kejadian Penyakit Tuberkulosis (TB) Paru di Wilayah Kerja Puskesmas Serang Kota Tahun 2019
}

\author{
Puji Eka Mathofani, Resti Febriyanti \\ Program Studi Kesehatan Masyarakat, Universitas Faletehan
}

\begin{abstract}
Abstrak
Latar Belakang: Tuberkulosis Paru di wilayah kerja Puskesmas Serang Kota merupakan kasus tertinggi pada tahun 2018. Penelitian ini bertujuan untuk mengetahui faktor-faktor yang berhubungan dengan kejadian penyakit TB Paru di Wilayah Kerja Puskesmas Serang Kota tahun 2019.

Metode: Desain penelitian yang digunakan adalah case control. Populasi penelitian ini sebagai kasus adalah pasien TB Paru dan populasi kontrol adalah orang yang bukan penderita TB Paru di Wilayah Kerja Puskesmas. Sampel pada penelitian ini berjumlah 74 responden terdiri dari 37 kasus dan 37 kontrol. Instrumen yang digunakan adalah kuesioner, lembar observasi, meteran dan thermometer. Data dianalisis secara univariat dan bivariat dengan uji chi square.

Hasil: Hasil penelitian didapatkan bahwa ada hubungan yang signifikan antara kepadatan hunian $(P v=0,018$ dan $O R=4,364)$, dan riwayat kontak serumah $(P v=0,011)$ dengan kejadian TB Paru, sedangkan tidak ada hubungan antara jenis lantai $(P v=0,115)$, suhu $(P v=0,778)$, dan kebiasaan merokok $(P v=0,416)$ dengan kejadian TB Paru.

Kesimpulan: disarankan bagi masyarakat lebih meningkatkan perilaku hidup bersih dan sehat untuk mencegah penyakit TB Paru. Bagi petugas kesehatan perlu ditingkatkan upaya penjaringan penemuan suspek maupun skrining $T B$.
\end{abstract}

Kata kunci: Tuberkulosis Paru, Kepadatan Hunian, Riwayat Kontak

\section{The Factors Associated With The Incidence Of Pulmonary Tuberculosis In The Working Area Of Serang City Health Center 2019}

\begin{abstract}
Background: Pulmonary tuberculosis in Serang City Public Health Center was the highest case in 2018. This study aims to determine the factors associated with the incidence of pulmonary TB in the working area of Serang City Public Health Center in 2019.

Method: This study used a case control design. The study population as a case is a pulmonary TB patient and the control population is a person who is not a sufferer of pulmonary TB in the working area of Public Health Center. The sample in this study amounted to 74 respondents consisting of 37 cases and 37 controls. The instruments used were questionnaire, observation sheet, roll meter and thermometer. Data were analyzed univariable and bivariable with chi square test.

Result: The results showed that there was a significant relationship between occupancy density $(P=0,018$ and $O R=4,364)$, and home contact history $(P=0,011)$ and pulmonary $T B$ events, whereas there was no relationship between floor type $(P=0,115)$, temperature $(P=0,778)$, and smoking habits $(P=0,416)$ with pulmonary TB events.

Conclusion: The advice given to the community further enhances clean and healthy living behavior to prevent pulmonary TB disease. Health workers need to be increased efforts to screen suspicion discovery and TB screening.
\end{abstract}

Keywords: Pulmonary tuberculosis, Occupancy Density, Contact History

Alamat korespondensi:

Puji Eka Mathofani

Universitas Faletehan

Email: pujimathofani@gmail.com 


\section{PENDAHULUAN}

Tuberkulosis adalah suatu penyakit menular yang disebabkan oleh bakteri Mycobacterium tuberculosis, bakteri ini biasanya menyerang paruparu, tetapi bakteri TB dapat menyerang bagian tubuh mana saja seperti ginjal, tulang belakang, dan otak. TB merupakan salah satu dari 10 penyebab kematian dan pembunuh utama penderita HIV di seluruh dunia. ${ }^{1}$

Secara global pada tahun 2017 jumlah tertinggi kasus TB terjadi di wilayah Asia Tenggara dan Pasifik Barat dengan 62\% kasus baru, diikuti oleh wilayah Afrika dengan 25\% kasus baru. Kasus TB terjadi di 30 negara sebesar $87 \%$, delapan negara menyumbang dua pertiga dari kasus TB baru yaitu India, Cina, Indonesia, Filipina, Pakistan, Nigeria, Bangladesh, dan Afrika Selatan. ${ }^{1}$ Indonesia bersama 13 negara lain, masuk dalam daftar HBC (high burden countries) untuk ke 3 indikator yaitu TBC, TBC/HIV, dan MDR- TBC. ${ }^{2}$

Indonesia memiliki permasalahan besar dalam menghadapi penyakit TB. Kasus tuberkulosis di Indonesia dalam kurun tiga tahun terakhir ini mengalami tren karena kasus terus meningkat setiap tahunnya. Pada tahun 2015 jumlah kasus tuberkulosis yang ditemukan sebesar 330.910 kasus, tahun 2016 sebesar 360.565 kasus, dan tahun 2017 sebesar 425.089 kasus. Berdasarkan Survei Prevalensi Tuberkulosis tahun 2013-2014, prevalensi TB dengan konfirmasi bakteriologis di Indonesia sebesar 759 per 100.000 penduduk berumur 15 tahun ke atas dan prevalensi TB BTA positif sebesar 257 per 100.000 penduduk berumur 15 tahun ke atas. ${ }^{3}$

Hasil data dan Informasi di Propinsi Banten diperoleh jumlah penderita TB paru tahun 2017 sebesar 13.837 kasus, dengan BTA positif sebesar 7.400 kasus. Tingginya jumlah penderita TB paru di Propinsi Banten, menduduki peringkat ke 16 di Indonesia. ${ }^{4}$ Riset Kesehatan Dasar tahun 2018 menyebutkan bahwa Propinsi Banten termasuk propinsi dengan prevalensi kasus TB paru tertinggi di Indonesia dengan prevalensi sebesar $0,8 \%$, meningkat dibandingkan tahun 2015 yaitu sebesar 0,4\%.

Berdasarkan laporan 10 besar penyakit di Kota Serang tahun 2018 kasus TB paru BTA positif menempati urutan ke empat setelah penyakit demam typhoid, diare dan dysentri. Jumlah kasus BTA positif pada tahun 2017 di Kota Serang sebanyak 678 kasus. Pada tahun 2018 ditemukan suspek TB paru sebanyak 1.619 orang, penderita TB paru yang sembuh 580 orang. ${ }^{5}$ Kasus BTA positif tertinggi pada tahun 2018 terjadi di Puskesmas Serang Kota sebanyak 66 kasus. ${ }^{22}$ Pada tahun 2019 bulan Januari sampai Maret ditemukan kasus BTA positif sebanyak 20 orang.
Dalam perspektif epidemiologi yang melihat kejadian penyakit sebagai hasil interaksi antar tiga komponen pejamu (host), penyebab (agent), dan lingkungan (environment) dapat ditelaah faktor risiko dari simpul-simpul tersebut. ${ }^{3}$ Agen penyebab penyakit TB paru disebabkan oleh bakteri Mycobacterium tuberculosis, penyakit ini menular langsung melalui droplet orang yang telah terinfeksi ${ }^{6}$. Salah satu faktor yang berperan dalam penyebaran kuman tuberkulosis adalah faktor lingkungan yaitu keadaan rumah yang tidak memenuhi syarat kesehatan meliputi ventilasi, pencahayaan, jenis lantai, jenis dinding, kelembaban, suhu dan kepadatan hunian. ${ }^{7}$

$\begin{array}{clr}\text { Kepadatan } & \text { hunian berpotensi } \\ \text { meningkatkan risiko penularan penyakit }\end{array}$ menular terhadap orang yang tinggal di dalamnya, semakin padat maka perpindahan penyakit khususnya penyakit menular melalui udara akan semakin mudah dan cepat. Kepadatan hunian yang tidak memenuhi syarat memiliki risiko untuk terjadinya TB paru 16,15 kali lebih besar dibandingkan dengan kepadatan hunian yang memenuhi syarat. ${ }^{8}$

Lantai rumah yang sehat adalah lantai yang kedap air sebagai syarat rumah yang sehat. Bahan yang digunakan meliputi kayu, semen, keramik, atau ubin. Lantai yang berdebu, kotor atau lembab akan membuat rumah menjadi sarang penyakit, maka dalam pemilihan bahan material lantai sangat penting. Lantai rumah menjadi faktor yang mempengaruhi kejadian $\mathrm{TB}$ paru, rumah yang memiliki lantai dari semen dan tidak rata menyebabkan lantai tidak mudah dibersihkan karena walaupun sudah dibersihkan terkadang ada air menggenang sehingga lantai menjadi lembab. Hasil penelitian sebelumnya menemukan bahwa bahwa jenis lantai memiliki hubungan yang signifikan dengan kejadian penyakit TB paru. $^{9}$

Bakteri penyebab tuberkulosis bisa hidup tahan lama di ruangan berkondisi gelap, lembab, dingin, dan tidak memiliki ventilasi yang baik. Oleh karena itu pembangunan rumah tempat tinggal yang memenuhi syarat kesehatan harus selalu diperhatikan sehingga risiko terjadinya penyakit yang disebabkan oleh kualitas udara yang buruk dapat dikurangi. ${ }^{10}$ 
Mycobacterium tuberculosis, dimana laju pertumbuhan basil tersebut ditentukan berdasarkan suhu udara yang berada di sekitarnya. Dengan adanya sirkulasi udara yang baik dapat meminimalisasi penularan TB Paru dalam rumah dan suhu ditemukan adanya signifikansi dengan kejadian penyakit TB paru. $^{11}$

Seseorang kontak dengan penderita TB paru BTA+ serumah/tinggal bersama secara terus-menerus maka akan terjadi penularan. Karena sering menghirup udara yang mengandung bakteri tersebut menyebabkan banyaknya kuman yang masuk ke paru-paru sehingga memiliki risiko untuk menderita TB paru. Kontak serumah dengan penderita TB paru, semakin banyak terpapar dengan kuman TB paru, maka memiliki risiko terkena penyakit TB paru. Riwayat kontak memiliki risiko untuk terjadinya TB paru 9,3 kali lebih besar dibandingkan dengan tidak adanya riwayat kontak. $^{12}$

Kebiasaan merokok merupakan faktor pemicu yang juga meningkatkan risiko untuk terkena TB paru. Merokok adalah menghisap racun yang dapat merusak kesehatan sehingga mudah terinfeksi berbagai penyakit salah satunya bakteri tuberkulosis. Risiko terjainya TB Paru 17,500 kali lebih besar pada responden dengan kebiasaan merokok dibanding responden dengan yang tidak merokok. ${ }^{13}$ Rumah sehat merupakan keadaan lingkungan yang mendukung terpeliharanya kesehatan para penghuni secara optimal. Adapun cakupan rumah sehat di wilayah kerja Puskesmas Serang Kota tahun 2018 sebesar $38 \%$.

Kasus BTA+ di Puskesmas Serang Kota merupakan yang tertinggi dibandingkan dengan kasus BTA+ di wilayah kerja Puskesmas lainnya yang berada di Kota Serang. Cakupan rumah sehat di wilayah kerja Puskesmas Serang Kota masih rendah dibandingkan dengan capaian target. Hasil studi pendahuluan yang dilakukan pada penderita TB sebagian besar memiliki kebiasaan merokok terutama laki-laki dan kepadatan hunian kamar yang tidak memenuhi syarat.

\section{METODE}

Studi observasional dengan jenis desain case control dilaksanakan di wilayah kerja Puskesmas Serang Kota pada bulan April-Mei tahun $2019 .{ }^{23}$ Kelompok kasus adalah penderita yang terdiagnosis disertai hasil uji laboratorium BTA+ dan bertempat tinggal di wilayah kerja Puskesmas Serang kota pada bulan Oktober tahun 2018 sampai dengan Maret tahun 2019 yakni berjumlah 37 kasus. Jumlah kontrol diambil sama dengan jumlah kasus. Pengambilan sampel untuk kelompok kasus dan kontrol diambil secara acak dengan memenuhi kriteria inklusi.

Variabel penelitian ini adalah kepadatan hunian, jenis lantai, suhu, riwayat kontak dan kebiasaan merokok. Pengumpulan data primer diperoleh dari survei, observasi dan pengukuran terhadap rumah responden dan data sekunder dari penulusuran buku-buku, karya ilmiah, penelitian terdahulu, laporan dari Dinas Kesehatan Kota Serang dan Puskesmas Serang Kota tahun 2018-2019. Alat penelitian yang digunakan adalah kuesioner, meteran untuk mengukur kepadatan hunian, lembar observasi dan thermometer untuk mengukur jenis lantai dan suhu. Analisis data meliputi analisis univariat dan bivariat. Analisis univariat yaitu secara deskriptif dengan menggunakan tabel distribusi frekuensi. Analisis bivariat yaitu secara analitik untuk mengetahui hubungan antara dua variabel dengan uji chi square.

\section{HASIL}

Berdasarkan tabel 1 diperoleh pada kelompok kasus dari 37 responden terdapat 32 (86,5\%) yang memiliki kepadatan hunian tidak memenuhi syarat. Sedangkan pada kelompok kontrol dari 37 responden terdapat $22(59,5 \%)$ yang memiliki kepadatan hunian tidak memenuhi syarat.

Tabel 1. Distribusi Frekuensi Kasus Tuberkulosis Paru Berdasarkan Kepadatan Hunian

\begin{tabular}{|c|c|c|c|c|}
\hline \multirow{3}{*}{$\begin{array}{l}\text { Kepadatan } \\
\text { Hunian }\end{array}$} & \multicolumn{4}{|c|}{$\begin{array}{c}\text { Kejadian Penyakit TB } \\
\text { Paru } \\
\end{array}$} \\
\hline & \multicolumn{2}{|c|}{ Kasus } & \multicolumn{2}{|c|}{ Kontrol } \\
\hline & $\mathbf{N}$ & $\%$ & $\mathrm{n}$ & $\%$ \\
\hline Tidak & 32 & 86,5 & 22 & 59,5 \\
\hline $\begin{array}{l}\text { Memenuhi } \\
\text { Syarat }\end{array}$ & & & & \\
\hline $\begin{array}{l}\text { Memenuhi } \\
\text { Syarat }\end{array}$ & 5 & 13,5 & 15 & 40,5 \\
\hline Jumlah & 37 & 100 & 37 & 100 \\
\hline
\end{tabular}


Tabel 2. Distribusi Frekuensi Kasus Tuberkulosis Paru Berdasarkan Jenis Lantai

\begin{tabular}{|c|c|c|c|c|}
\hline \multirow{3}{*}{$\begin{array}{l}\text { Jenis } \\
\text { Lantai }\end{array}$} & \multicolumn{4}{|c|}{$\begin{array}{c}\text { Kejadian Penyakit TB } \\
\text { Paru } \\
\end{array}$} \\
\hline & \multicolumn{2}{|c|}{ Kasus } & \multicolumn{2}{|c|}{ Kontrol } \\
\hline & $\mathbf{N}$ & $\%$ & $\underline{\mathbf{n}}$ & $\%$ \\
\hline $\begin{array}{l}\text { Tidak } \\
\text { Memenuhi } \\
\text { Syarat }\end{array}$ & 4 & 10,8 & 0 & 0 \\
\hline $\begin{array}{l}\text { Memenuhi } \\
\text { Syarat }\end{array}$ & 33 & 89,2 & 37 & 100 \\
\hline Jumlah & $\underline{37}$ & 100 & $\underline{37}$ & 100 \\
\hline
\end{tabular}

Berdasarkan tabel 2 diperoleh pada kelompok kasus dari 37 responden terdapat 4 $(10,8 \%)$ yang memiliki jenis lantai tidak memenuhi syarat. Sedangkan pada kelompok kontrol dari 37 responden tidak terdapat $(0 \%)$ yang memiliki jenis lantai tidak memenuhi syarat.

Tabel 3. Distribusi Frekuensi Kasus Tuberkulosis Paru Berdasarkan Suhu

\begin{tabular}{|c|c|c|c|c|}
\hline \multirow{3}{*}{ Suhu } & \multicolumn{4}{|c|}{$\begin{array}{c}\text { Kejadian Penyakit TB } \\
\text { Paru }\end{array}$} \\
\hline & \multicolumn{2}{|c|}{ Kasus } & \multicolumn{2}{|c|}{ Kontrol } \\
\hline & $n$ & $\%$ & $\bar{n}$ & $\%$ \\
\hline $\begin{array}{l}\text { Tidak } \\
\text { Memenuhi } \\
\text { Syarat }\end{array}$ & 30 & $8 \overline{1,1}$ & 28 & 75 \\
\hline $\begin{array}{l}\text { Memenuhi } \\
\text { Syarat }\end{array}$ & 7 & 18,9 & 9 & 24,3 \\
\hline Jumlah & 37 & 100 & 37 & \\
\hline
\end{tabular}

Berdasarkan tabel 3 diperoleh pada kelompok kasus dari 37 responden terdapat $30(81 \%)$ yang memiliki suhu tidak memenuhi syarat. Sedangkan pada kelompok kontrol dari 37 responden terdapat $28(76 \%)$ yang memiliki suhu tidak memenuhi syarat.

\section{Tabel 4. Distribusi Frekuensi Kasus Tuberkulosis Paru Berdasarkan Riwayat Kontak}

\begin{tabular}{|c|c|c|c|c|}
\hline \multirow{3}{*}{$\begin{array}{l}\text { Riwayat } \\
\text { Kontak } \\
\text { Serumah }\end{array}$} & \multicolumn{4}{|c|}{$\begin{array}{c}\text { Kejadian Penyakit TB } \\
\text { Paru }\end{array}$} \\
\hline & \multicolumn{2}{|c|}{ Kasus } & \multicolumn{2}{|c|}{ Kontrol } \\
\hline & $\mathbf{N}$ & $\%$ & $\underline{\mathbf{N}}$ & $\%$ \\
\hline & 7 & & & 0 \\
\hline 1dak & $\underline{30}$ & $\underline{81,1}$ & 37 & $\underline{100}$ \\
\hline Jumlah & 37 & 100 & 37 & 100 \\
\hline
\end{tabular}

Berdasarkan tabel 4 diperoleh pada kelompok kasus dari 37 responden yang menderita TB Paru terdapat 7 (19\%) yang ada riwayat kontak dengan penderita TB Paru. Sedangkan dari pada kelompok kontrol 37 responden tidak terdapat $(0 \%)$ yang ada riwayat kontak dengan penderita TB Paru.

\section{Kebiasaan Merokok}

Tabel 5. Distribusi Frekuensi Kasus Tuberkulosis Paru Berdasarkan Kebiasaan merokok

\begin{tabular}{|c|c|c|c|c|}
\hline \multirow{3}{*}{$\begin{array}{c}\text { Kebiasaan } \\
\text { Merokok }\end{array}$} & \multicolumn{4}{|c|}{$\begin{array}{c}\text { Kejadian Penyakit TB } \\
\text { Paru }\end{array}$} \\
\hline & \multicolumn{2}{|c|}{ Kasus } & \multicolumn{2}{|c|}{ Kontrol } \\
\hline & $\mathrm{n}$ & $\%$ & $\overline{\mathbf{N}}$ & $\%$ \\
\hline Ya & 26 & $7 \overline{70,3}$ & 30 & $8 \overline{1,1}$ \\
\hline Tidak & $\underline{11}$ & 29,7 & 7 & $\underline{18,9}$ \\
\hline Jumlah & 37 & 100 & $\underline{37}$ & $\underline{100}$ \\
\hline
\end{tabular}

Berdasarkan tabel 5 diperoleh pada kelompok kasus dari 37 responden terdapat 26 $(70,3 \%)$ yang memiliki kebiasaan merokok. Sedangkan pada kelompok kontrol dari 37 responden terdapat $30(81 \%)$ yang memiliki kebiasaan merokok.

Berdasarkan hasil uji statistik dengan menggunakan uji chi square diperoleh nilai $\mathrm{P}=0,018$ maka dapat disimpulkan secara statistik pada $\alpha \quad 5 \%$ ada hubungan yang signifikan antara kepadatan hunian kamar dengan kejadian penyakit tuberkulosis paru di Wilayah Kerja Puskesmas Serang Kota tahun 2019. Dan dari hasil analisis diperoleh nilai OR sebesar 4,364 (CI: 1,384-13,761) artinya responden yang memiliki kepadatan hunian kamar tidak memenuhi syarat kesehatan mempunyai risiko 4 kali lebih besar untuk terkena penyakit tuberkulosis paru dibandingkan dengan responden yang kepadatan hunian kamarnya memenuhi syarat kesehatan.

Berdasarkan hasil uji statistik dengan menggunakan uji chi square diperoleh nilai $\mathrm{P}=0,115$ maka dapat disimpulkan secara statistik pada $\alpha 5 \%$ tidak ada hubungan yang signifikan antara jenis lantai rumah dengan kejadian penyakit tuberkulosis paru di Wilayah Kerja Puskesmas Serang Kota tahun 2019. 


\section{Analisis Bivariat}

Tabel 6. Analisis Bivariat

\begin{tabular}{|c|c|c|c|c|c|c|c|c|}
\hline \multirow{3}{*}{ Variabel } & \multicolumn{4}{|c|}{ Kejadian Penyakit TB Paru } & \multirow{2}{*}{\multicolumn{2}{|c|}{ Total }} & \multirow{3}{*}{$\begin{array}{r}P \\
\text { alue }\end{array}$} & \multirow{3}{*}{ OR $(95 \% \mathrm{CI})$} \\
\hline & \multicolumn{2}{|c|}{ Kasus } & \multicolumn{2}{|c|}{ Kontrol } & & & & \\
\hline & $\mathbf{n}$ & $\%$ & $\mathbf{N}$ & $\%$ & $\mathbf{n}$ & $\%$ & & \\
\hline Kepadatan Hunian & & & & & & & \multirow{3}{*}{$n \cap 18$} & \multirow{6}{*}{$\begin{array}{c}4,364 \\
(1,384-13,761)\end{array}$} \\
\hline Tidak Memenuhi Syarat & 32 & 86,5 & 22 & 59,5 & 54 & 73 & & \\
\hline Memenuhi Syarat & 5 & 13,5 & 15 & 40,5 & 20 & 27 & & \\
\hline Jenis Lantai & & & & & & 5,4 & \multirow{3}{*}{0,115} & \\
\hline Tidak Memenuhi Syarat & 4 & 10,8 & 0 & 0 & 4 & & & \\
\hline Memenuhi Syarat & 33 & 89,2 & 37 & 100 & 70 & 94,6 & & \\
\hline Suhu & & & & & & & \multirow{3}{*}{ n 778} & \\
\hline Tidak Memenuhi Syarat & 30 & 81,1 & 28 & 75,7 & 58 & 78,4 & & \multirow{7}{*}{$\begin{array}{c}1,378 \\
(0,452-4,196)\end{array}$} \\
\hline Memenuhi Syarat & 7 & 18,9 & 9 & 24,3 & 16 & 21,6 & & \\
\hline Riwayat Kontak Serumah & & & & & & 9,5 & \multirow{3}{*}{0,011} & \\
\hline Ada & 7 & 18,9 & 0 & 0 & 7 & & & \\
\hline Tidak Ada & 30 & 81,1 & 37 & 100 & 67 & 90,5 & & \\
\hline $\begin{array}{l}\text { Kebiasaan Merokok } \\
\text { Ya }\end{array}$ & 26 & 70,3 & 30 & 81.1 & 56 & 75,7 & \multirow{2}{*}{0,416} & \\
\hline Tidak & 11 & 29,7 & 7 & 18,9 & 18 & 24,3 & & \\
\hline Total & 37 & 100 & 37 & 100 & 74 & 100 & & \\
\hline
\end{tabular}

Berdasarkan hasil uji statistik dengan menggunakan uji chi square diperoleh nilai $\mathrm{P}=0,778$ maka dapat disimpulkan secara statistik pada $\alpha 5 \%$ tidak ada hubungan yang signifikan antara suhu dengan kejadian penyakit tuberkulosis paru di Wilayah Kerja Puskesmas Serang Kota tahun 2019. Dan dari hasil analisis diperoleh nilai OR sebesar 1,378 (CI: 0,452$4,196)$ artinya responden yang memiliki suhu tidak memenuhi syarat kesehatan mempunyai risiko 1 kali lebih besar untuk terkena pennyakit tuberkulosis paru dibandingkan dengan responden yang memiliki suhu memenuhi syarat kesehatan.

Berdasarkan hasil uji statistik dengan menggunakan uji chi square diperoleh nilai $\mathrm{P}=0,011$ maka dapat disimpulkan secara statistik pada $\alpha 5 \%$ ada hubungan yang signifikan antara riwayat kontak serumah dengan kejadian penyakit tuberkulosis paru di Wilayah Kerja Puskesmas Serang Kota tahun 2019.

Berdasarkan hasil uji statistik dengan menggunakan uji chi square diperoleh nilai $\mathrm{P}=0,416$ maka dapat disimpulkan secara statistik pada $\alpha 5 \%$ tidak ada hubungan yang signifikan antara kebiasaan merokok dengan kejadian penyakit tuberkulosis paru di Wilayah Kerja Puskesmas Serang Kota tahun 2019.

\section{PEMBAHASAN}

\section{Hubungan Antara Kepadatan Hunian Dengan Kejadian Penyakit Tuberkulosis Paru di Wilayah Kerja Puskesmas Serang Kota Tahun 2019}

Kepadatan hunian berpengaruh dalam proses penularan penyakit, semakin padat perpindahan penyakit menular khususnya yang melalui udara akan semakin mudah dan cepat. Apabila jumlah penghuni semakin banyak di dalam ruangan, maka akan meningkatkan kelembaban ruangan karena uap air baik dari pernapasan maupun keringat yang keluar dari tubuh. Kepadatan hunian kamar yang sesuai dengan rumah sehat yaitu luas kamar tidur minimum $8 \mathrm{~m}^{2} /$ orang, tidak dihuni $>2$ orang, kecuali untuk anak dibawah 5 tahun. Dan jika ada anggota keluarga yang menderita penyakit tuberkulosis paru, sebaiknya tidur terpisah dengan anggota keluarga lainnya. ${ }^{14}$

Hasil analisis tabel silang antara kepadatan hunian dengan kejadian penyakit tuberkulosis paru diperoleh pada kelompok kasus lebih banyak responden yang memiliki kepadatan hunian tidak memenuhi syarat kesehatan yaitu sebesar 86,5\% dibandingkan pada kelompok kontrol yaitu sebesar $59,5 \%$. 
Berdasarkan analisis bivariat dengan menggunakan uji chi square diperoeh nilai $\mathrm{P}=0,018$ maka ada hubungan yang signifikan antara kepadatan hunian dengan kejadian penyakit tuberkulosis paru di Wilayah Kerja Puskemsas Serang Kota Tahun 2019. Dan dari hasil analisis diperoleh nilai $\mathrm{OR}=4,364$ yang artinya responden yang memiliki kepadatan hunian tidak memenuhi syarat kesehatan berisiko 4 kali lebih besar terkena penyakit tuberkulosis paru dibandingkan dengan responden yang memiliki kepadatan hunian memenuhi syarat kesehatan.

Hasil penelitian ini sejalan dengan hasil penelitian berjudul Hubungan Faktor Lingkungan Fisik Rumah terhadap Kejadian TB Paru dimana pada kelompok kasus kepadatan hunian yang tidak memenuhi syarat kesehatan lebih besar yaitu 64\% dibandingkan kelompok kontrol sebesar $14 \%$. Diperoleh nilai $\mathrm{P}=0,000$ yang artinya ada hubungan antara kepadatan hunian dengan kejadian TB Paru dengan nilai OR sebesar 10,92 yang menunjukan bahwa responden yang memiliki kepadatan hunian tidak memenuhi syarat kesehatan berisiko 10,92 kali lebih besar dibandingkan dengan responden yang memiliki kepadatan hunian memenuhi syarat kesehatan. ${ }^{8}$ Hasil penelitian di wilayah kerja Puskesmas Kertapati Palembang menyatakan bahwa ada hubungan antara kepadatan hunian dengan kejadian penyakit tuberkulosis paru $(\mathrm{P}=0,002) .{ }^{15}$ Sama halnya penelitian di wilayah kerja Puskesmas Tikala Baru Kota Manado yang menyatakan bahwa ada hubungan antara kepadatan hunian dengan kejadian penyakit $(\mathrm{P}=0,049) .{ }^{16}$

Dari hasil kunjungan lapangan yang dilakukan melalui wawancara dan pengukuran pada luas kamar tidur dan jumlah penghuni diketahui hampir sebagian responden memiliki kepadatan hunian kamar tidak memenuhi syarat sebesar $73 \%$ dibandingkan dengan jumlah responden yang kepadatan hunian kamarnya memenuhi syarat sebesar $27 \%$. Berdasarkan hasil observasi sebagian besar responden kasus kamar tidurnya tidak terpisah dengan anggota keluarganya yang sehat bahkan ada responden kasus yang tidak memiliki kamar, hal tersebut disebabkan karena keterbatasan lahan. Berdasarkan hasil analisis menunjukan bahwa kepadatan hunian ada hubungan dengan kejadian penyakit tuberkulosis paru. Hal ini dapat dilihat dari data sebagian besar luas kamar tidur responden dan jumlah penghuni tidak memenuhi syarat karena kurang dari $8 \mathrm{~m}^{2} /$ orang.

\section{Hubungan Antara Jenis Lantai Dengan Kejadian Penyakit Tuberkulosis Paru di Wilayah Kerja Puskesmas Serang Kota Tahun 2019}

Jenis lantai tanah berperan terhadap proses kejadian $\mathrm{TB}$, melalui kelembaban dengan jenis lantai tanah cenderung menjadi lembab maka viabilitas bakteri TB di lingkungan juga sangat dipengaruhi. ${ }^{17}$ Bahan yang digunakan misalnya seperti semen, keramik, atau ubin. Lantai yang berdebu atau becek tidak membuat penghuni menjadi nyaman dan menjadi media berkembang biaknya penyakit. $^{14}$

Hasil analisis tabel silang antara jenis lantai dengan kejadian penyakit tuberkulosis paru diperoleh pada kelompok kasus responden yang memiliki jenis lantai tidak memenuhi syarat sedikit lebih banyak yaitu sebesar 10,8\% dibandingkan pada kelompok kontrol yaitu sebesar 0\%. Berdasarkan analisis bivariat dengan menggunakan uji chi square dipreoleh nilai $\mathrm{P}=0,115$ maka tidak ada hubungan yang signifikan antara jenis lantai dengan kejadian penyakit tuberkulosis paru di Wilayah Kerja Puskesmas Serang Kota Tahun 2019.

Penelitian ini sejalan dengan hasil penelitian di Wilayah Kerja Puskesmas Kasemen Kota Serang yang menyatakan bahwa tidak ada hubungan yang signifikan antara jenis lantai dengan kejadian penyakit tuberkulosis paru $(\mathrm{P}=0,437) .{ }^{18}$

Namun, hasil penelitian ini tidak sejalan dengan hasil penelitian Mawardi dkk yang menyatakan bahwa ada hubungan yang signifikan antara jenis lantai dengan kejadian penyakit tuberkulosis paru $(\mathrm{P}=0,015)$. Sama halnya dengan hasil penelitian Oktavia dkk dengan judul Analisis Faktor Risiko Kejadian TB Paru di Wilayah Kerja Puskesmas Kertapati Palembang yang menyatakan bahwa ada hubungan antara jenis lantai dengan kejadian penyakit tuberkulosis paru $(\mathrm{P}=0,001) .{ }^{9}$

Berdasarkan hasil analisis bahwa jenis lantai menunjukkan tidak ada hubungan dengan kejadian penyakit tuberkulosis paru. Dikarenakan pada observasi yang dilakukan hanya dengan melihat jenis lantainya saja tanpa memerhatikan kebersihannya. Meskipun lantainya terbuat dari yang kedap air namun kebersihan lantainya tidak terjaga maka lantai menjadi lembab dan menjadi media yang baik untuk berkembangbiaknya bakteri. Faktor lainnya juga yang mempengaruhi kejadian penyakit tuberkulosis seperti tidak adanya 
ventilasi atau ventilasi yang tidak memenuhi syarat dan jendela tidak pernah dibuka. Faktor tersebut menyebabkan kelembaban dan pencahayaan yang kurang, karena tidak ada jalan masuk untuk pertukaran udara dan sinar matahari langsung yang berfungsi sebagai pencahayaan alami maupun membunuh bakteri secara langsung.

\section{Hubungan Antara Suhu Dengan Kejadian Penyakit Tuberkulosis Paru di Wilayah Kerja Puskesmas Serang Kota Tahun 2019}

Suhu ruangan sangat dipengaruhi oleh suhu udara luar, pergerakan udara, kelembaban udara, dan suhu benda-benda yang ada di sekitarnya. Keberadaan suhu sangat berperan pada pertumbuhan basil Mycobacterium tuberculosis, dimana laju pertumbuhan basil tersebut ditentukan berdasarkan suhu udara yang berada di sekitarnya. ${ }^{11}$

Hasil analisis tabel silang antara suhu dengan kejadian penyakit tuberkulosis paru diperoleh pada kelompok kasus responden yang memiliki suhu tidak memenuhi syarat lebih banyak yaitu $81,1 \%$ dibandingkan pada kelompok kontrol yaitu 75,7\%. Berdasarkan analisis bivariat dengan menggunakan uji chi square diperoleh nilai $\mathrm{P}=0,778$ maka tidak ada hubungan yang signifikan antara suhu dengan kejadian penyakit tubekulosis paru di Wilayah Kerja Puskesmas Serang Kota Tahun 2019. Dan dari hasil analisis diperoleh nilai $\mathrm{OR}=1,376$ yang artinya responden yang memiliki suhu tidak memenuhi syarat kesehatan berisiko 1 kali lebih besar terkena penyakit tuberkulosis paru dibandingkan dengan responden yang memiliki suhu memenuhi syarat kesehatan. Hasil penelitian ini sejalan dengan hasil penelitian Susanti dengan judul Hubungan Antara Kondisi Fisik Rumah Dan Perilaku Dengan Kejadian Tuberkulosis Paru Di Wilayah Kerja Puskesmas Sangkrah Kota Surakarta yang menyatakan tidak ada hubungan antara suhu dengan kejadian penyakit tuberkulosis paru $(\mathrm{P}=0,212) .{ }^{19}$

Namun penelitian ini tidak sejalan dengan hasil penelitian Prihartanti, dkk dengan judul Hubungan Lingkungan Fisik Rumah Dengan Kejadian TB Paru di Wilayah Kerja Puskesmas Mirit Kabupaten Kebumen yang menyatakan bahwa ada hubungan antara jenis lantai dengan kejadian penyakit tuberkulosis paru $(\mathrm{P}=0,003) .{ }^{11}$
Berdasarkan hasil analisis bahwa suhu menunjukkan tidak ada hubungan dengan kejadian penyakit tuberkulosis paru. Hasil pengukuran ini dapat dipengaruhi oleh suhu udara luar. Selain itu, juga dipengaruhi kelembaban rumah, jendela yang tidak dibuka dan ventilasi yang tertutup kaca. Berdasarkan teori suhu ruangan tergantung dari suhu udara luar, pergerakan udara, kelembaban udara, dan suhu benda di sekitarnya. Keterbatasan dalam penelitian ini adalah tidak dilakukan pengukuran suhu udara luar dan pergerakan udara. Penyebab hasil penelitian tidak berhubungan dapat disebakan karena faktor lain, seperti kelembaban, pencahayaan, luas ventilasi, dan keberadaan jendela.

\section{Hubungan Antara Riwayat Kontak Serumah Dengan Kejadian Penyakit Tuberkulosis Paru di Wilayah Kerja Puskesmas Serang Kota Tahun 2019}

Dalam etiologi penyakit tuberkulosis, bakteri mycobacterium tuberculosis Sumber penular adalah penderita TB BTA positif. Pada saat batuk atau bersin menyebarkan bakteri melalui udara dalam bentuk droplet. Droplet yang mengandung bakteri dapat bertahan pada suhu kamar dalam beberapa jam. Seseorang dapat terinfeksi bakteri TB apabila droplet tersebut terhirup ke dalam saluran napas. ${ }^{20}$

Hasil analisis tabel silang antara riwayat kontak serumah dengan kejadian penyakit tuberkulosis paru diperoleh pada kelompok kasus sedikit lebih banyak responden yang ada riwayat kontak serumah sebesar 18,9\% dibandingkan pada kelompok kontrol yaitu $0 \%$.

Berdasarkan analisis bivariat dengan menggunakan uji chi square diperoleh nilai $\mathrm{P}=0,011$ maka ada hubungan yang signifikan antara riwayat kontak serumah dengan kejadian penyakit tubekulosis paru di Wilayah Kerja Puskesmas Serang Kota Tahun 2019.

Hasil penelitian ini sejalan dengan hasil penelitian Amalaguswan, dkk (2017) dengan judul Analisis Faktor Risiko Kejadian Penyakit Paru di Wilayah Kerja Puskesmas Puuwatu Kota Kendari yang menyatakan bahwa ada hubungan yang signifikan antara riwayat kontak serumah dengan kejadian penyakit tuberkulosis paru $(\mathrm{P}=0,000)$. Dan diperoleh hasil $\mathrm{OR}$ sebesar 9,333 artinya responden yang ada riwayat kontak serumah berisiko 9 kali lebih besar terkena penyakit tuberkulosis paru dibandingkan 
dengan responden yang tidak ada riwayat kontak serumah. $^{12}$

Dari hasil kunjungan lapangan yang dilakukan melalui wawancara langsung dengan responden diperoleh sebanyak 7 responden ada kontak dengan penderita TB Paru positif yang tinggal dalam satu rumah yang masih dalam pengobatan atau kurun waktu 6 bulan terakhir. Keberadaan kontak serumah mempengaruhi proses penularan kepada anggota keluarga yang lain. Pada umumnya penularan terjadi dalam ruangan dimana droplet (percikan dahak) ada dalam waktu yang lama. Bakteri yang ada dalam droplet dapat bertahan beberapa jam dalam kondisi gelap dan lembab. Anggota keluarga dapat terinfeksi jika terus-menerus menghirup droplet yang kemudian masuk ke dalam saluran pernapasan. Dikarenakan penderita TB paru lebih lama dan sering melakukan kontak kepada anggota keluarga sehingga risiko penularan penyakit lebih besar. Dengan demikian adanya riwayat kontak serumah menjadi pemicu terjadinya penularan bakteri mycobacterium tuberkulosis pada anggota keluarga yang tinggal dalam serumah.

\section{Hubungan Antara Kebiasaan Merokok Dengan Kejadian Penyakit Tuberkulosis Paru di Wilayah Kerja Puskesmas Serang Kota Tahun 2019}

Merokok merupakan penyebab utama penyakit paru-paru yang bersifat kronis dan obstruktif, misalnya bronkitis dan emfisema. Merokok juga terkait dengan influenza dan radang paru-paru lainnya. Pada penderita asma, merokok akan memperparah gejala asma sebab asap rokok akan lebih menyempitkan saluran pernafasan $^{21}$.

Hasil analisis tabel silang antara kebiasaan merokok dengan kejadian penyakit tuberkulosis paru diperoleh pada kelompok kontrol responden yang memiliki kebiasaan merokok lebih banyak yaitu $81,1 \%$ dibandingkan pada kelompok kasus yaitu $70,3 \%$.

Berdasarkan analisis bivariat dengan menggunakan uji chi square diperoleh nilai $\mathrm{P}=0,416$ maka tidak ada hubungan yang signifikan antara kebiasaan merokok dengan kejadian penyakit tubekulosis paru di Wilayah Kerja Puskesmas Serang Kota Tahun 2019.
Penelitian ini tidak sejalan dengan hasil penelitian Banu dkk dengan judul Faktor Risiko Kejadian TB Paru di Puskesmas Hutarakyat Sidikalang yang menyatakan ada hubungan yang signifikan antara kebiasaan merokok dengan kejadian penyakit tuberkulosis paru $(\mathrm{p}=0,001)^{13}$.

Berdasarkan hasil analisis bahwa kebiasaan merokok menunjukkan tidak ada hubungan dengan kejadian penyakit tuberkulosis paru. Dari hasil lapangan diperoleh sebagian besar responden memiliki kebiasaan merokok sebesar 75,7\%. Pada kelompok kasus diketahui lebih banyak responden yang menderita TB Paru dengan jenis kelamin laki-laki yaitu sebesar 22 $(59,5 \%)$ responden dibandingkan dengan jenis kelamin perempuan sebanyak $15(40,5 \%)$. Dari 22 responden laki-laki diketahui sebanyak 18 $(81,8 \%)$ responden memiliki kebiasaan merokok. Hal ini sesuai menurut survei prevalensi tuberkulosis pada laki-laki 3 kali lebih tinggi dibandingkan pada perempuan. Walaupun merokok bukan merupakan faktor yang berhubungan dengan kejadian penyakit TB Paru namun sebagai faktor pemicu. Penyakit lain seperti HIV/AIDS juga merupakan faktor pemungkin terjadinya penyakit TB Paru karena status imun menjadi lemah sehingga mudah untuk terkena penyakit lainnya. Penemuan kasus TB tidak selalu terdiagnosa di awal, beberapa ada yang terlebih dulu diketahui penyakit lain seperti HIV/AIDS dan kemudian barulah TB Paru.

Faktor lainnya yang memiliki peranan dalam penularan penyakit tuberkulosis adalah lingkungan. Lingkungan yang buruk menjadi media yang baik untuk perkembangbiakan bakteri Mycobacterium tuberculosis. Keadaan lingkungan fisik rumah maupun lingkungan di luar berperan dalam proses penularan penyakit. Kepadatan hunian, pencahayaan, kelembaban, dan ventilasi merupakan indikator yang diukur, jika tidak memenuhi syarat maka berisiko terjadi penularan penyakit. Kurangnya cahaya matahari atau cahaya lampu, keadaan ruang yang gelap dan lembab menyebabkan bakteri TB paru dapat bertahan sehingga mempunyai peluang besar untuk menimbulkan kasus TB paru. Pengukuran yang dilakukan pada responden kasus meliputi kepadatan hunian, jenis lantai, dan suhu hasilnya memenuhi syarat, tidak ada riwayat kontak serumah dan tidak memiliki kebiasaan merokok. Namun, keseharian responden sering berada di warung internet (warnet) yang keadaannya tertutup, gelap, padat huni dan penuh asap rokok, hal ini menjadi faktor risiko terjadinya penularan penyakit TB. Maka kondisi fisik lingkungan yang berisiko tidak hanya di rumah 
saja, melainkan di tempat-tempat umum seperti warung internet juga berpotensi menularkan penyakit TB Paru.

\section{KESIMPULAN}

Proporsi kepadatan hunian kamar tidak memenuhi syarat kesehatan lebih tinggi pada kelompok kasus dibandingkan kelompok control. Begitu pula pada jenis lantai rumah, suhu, dan riwayat kontak serumah. Namun berbeda pada kebiasaan merokok proporsinya lebih tinggi pada kelompok control dibandingkan kasus.

Terdapat hubungan antara kepadatan hunian dan riwayat kontak serumah dengan kejadian penyakit tuberkulosis paru di Wilayah Kerja Puskemas Serang Kota tahun 2019. Sedangkan jenis lantai, suhu, dan kebiasaan merokok tidak ada hubungan yang signifikan dengan kejadian penyakit tuberkulosis paru di Wilayah Kerja Puskemas Serang Kota tahun 2019

\section{DAFTAR PUSTAKA}

1. WHO. (2018). Global Tuberculosis Report. Geneva: World Health Organization.

2. WHO. (2017). Global Tuberculosis Report. Geneva: World Health Organization.

3. Kemenkes RI. (2018). Riset Kesehatan Dasar. Jakarta.

4. Kemenkes RI. (2017). Profil Kesehatan Indonesia Tahun 2017. Jakarta.

5. Dinkes Kota Serang. (2018). Profil Kesehatan Kota Serang. Serang.

6. Najmah. (2016). Epidemiologi Penyakit Menular. Jakarta: Trans Info Media.

7. Kemenkes RI. (2011). Pedoman Nasional Pengendalian Tuberkulosis. Jakarta.

8. Perdana, A. A., \& Putra, S. Y. (2018). Hubungan Faktor Lingkungan Fisik Rumah terhadap Kejadian TB Paru di Wilayah Kerja Puskesmas Panjang, Lampung. Jurnal Kesehatan, 46-50.
9. Mawardi, Sambera, R., \& Hamisah, I. (2019). Studi Hubungan Antara Faktor Lingkungan Fisik Rumah Dengan Penderita TB Paru BTA di Aceh Selatan. Serambi Engineering, 406-415.

10. Permenkes. (2011). Peraturan Menteri Kesehatan Republik Indonesia Nomor 1077 Tentang Pedoman Penyehatan Udara Dalam Ruang Rumah. Jakarta.

11. Prihartanti, D., Subagiyo, A., \& Suparmin. (2018). Hubungan Lingkungan Fisik Rumah dengan Kejadian TB Paru di Wilayah Kerja Puskesmas Mirit Kabupaten Kebumen Mirit Kabupaten Kebumen Tahun 2016. Jurnal Kesehatan Lingkungan, 386-392.

12. Amalaguswan, Junaid, \& Fachlevy, A. F. (2017). Analisis Faktor Risiko Kejadian Penyakit TB Paru di Wilayah Kerja Puskesmas Puuwatu Kota Kendari Tahun 2017. Jurnal Ilmiah Mahasiswa Kesehatan Masyarakat, 1-9.

13. Banu, S., Sitepu, R., \& Sulistiasari, R. (2018). Faktor Risiko Kejadian TB Paru di Puskesmas Hutarakyat Sidikalang Tahun 2017. Jurnal Ilmu Kedokteran dan Kesehatan, 254-263.

14. Kepmenkes. (1999). Persyaratan Kesehatan Perumahan. Jakarta.

15. Oktavia, S., Rini, M., \& Destriatania, S. (2016). Analisis Faktor Risiko Kejadian TB Paru di Wilayah Kerja Puskesmas Kertapati Palembang. Jurnal Ilmu Kesehatan Masyarakat, 124-138.

16. Tempone, V. M., Umboh, J. M., \& Boky, H. (2016). Hubungan Antara Kelembaban, Pencahayaan, Dan Kepadatan Hunian Dalam Rumah Dengan Kejadian TB Paru di Wilayah Kerja Puskesmas Tikala Baru Kota Manado. Jurnal Kesehatan Masyarakat, 47-53. 
17. Achmadi, U. F. (2010). Manajemen Penyakit Berbasis Wilayah. Jakarta: Bumi Aksara.

18. Juniarti. (2018). Faktor-Faktor Yang Berhubungan Dengan Kejadian Penyakit TB Paru di Desa Banten Wilayah Kerja Puskesmas Kasemen Kota Serang Tahun 2018. Skripsi. STIKes Faletehan. Serang

19. Susanti, L. I. (2016). Hubungan Antara Kondisi Fisik Rumah Dan Perilaku Dengan Kejadian Tuberkulosis Paru di Wilayah Kerja Puskesmas Sangkrah Kota Surakarta Tahun 2016. Publikasi Ilmiah, 1-14.
20. Kuswiyanto. (2017). Bakteriologi. Jakarta: EGC.

21. Wijaya, A. A. (2012). Merokok dan Tuberkulosis. Jurnal Tuberkulosis Indonesia, 18-23.

22. Puskesmas Serang Kota. (2018). Laporan Register Bulanan Penderita TB Paru. Serang.

23. Puskesmas Serang Kota. (2019). Laporan Register Bulanan Penderita TB Paru. Serang. 